Brazilian Journal

of Chemical

ISSN 0104-6632

Engineering

Printed in Brazil

www.abeq.org.br/bjche

Vol. 22, No. 02, pp. 227 -232, April - June, 2005

\title{
DRYING OF MUNICIPAL SEWAGE SLUDGE: FROM A LABORATORY SCALE BATCH INDIRECT DRYER TO THE PADDLE DRYER
}

\author{
P. Arlabosse ${ }^{1 *}$, S. Chavez ${ }^{1}$ and C. Prevot $^{2}$ \\ ${ }^{1}$ Laboratoire de Génie des Procédés des Solides Divisés (UMR 2392), \\ Ecole des Mines d'Albi Carmaux, Phone: +(33) 563493237, Fax:+(33) 563493243 \\ Route de Teillet, 81013 Albi CT Cedex 09, France, \\ E-mail: Patricia.Arlabosse@enstimac.fr \\ ${ }^{2}$ Degrémont, CERDEG, Direction Recherche et Développement, \\ 87 Chemin de Ronde, 78290 Croissy sur Seine, France
}

(Received: October 20, 2004 ; Accepted: November 20, 2004)

\begin{abstract}
Among available technologies, disk and paddle dryers are often encountered in France to process municipal sewage sludge but their thermal design is still a question of know how rather than scientific knowledge. From experiments performed on an industrial Naratherm ${ }^{\circledR}$ paddle dryer and the literature, a simple model has been developed. The dryer is divided into two parts depending on the sludge consistency. A constant evaporating flow rate is assumed in the pasty zone whereas its linear decrease with the moisture content is taken into account in the granular zone. To compute this model, some of the sludge properties have to be characterized with a set of laboratory scale experimental techniques. The agreement with the experimental data is good.

Keywords: Contact drying; Drying kinetic; Model; Experiment.
\end{abstract}

\section{INTRODUCTION}

Sludge management is an ever-increasing problem due to environmental pollution and energy consumption. Approximately, 850,000 tons of dry matter per year were generated in 1998 and an increase to some $1,300,000$ tons of dry matter per year is expected in the year 2005. Drying of sewage sludge is now widely recognized as an efficient means of processing municipal sewage sludge to a solid form that can easily be handled, stored and recycled. After the drying stage, agricultural spreading, landfill and incineration remain available disposal routes. Furthermore, the volume has been considerably reduced and, according to the long residence time at high temperature in most of the conventional dryers, the product is pasteurized.
Thermal drying of industrial sludge has been practiced for many decades but the developments for municipal sludge were rather confidential. In the late 1980s, interest renewed and manufacturers, who have successfully applied their technologies in chemical and food industries, tried to transfer existing technologies to sewage sludge (Chen et al, 2002). Nowadays, successful experiences in the thermal processing of sewage sludge rest with a few companies but the dryer design remains a question of know how rather than scientific knowledge. Among available technologies, disk and paddle dryers are often encountered in France. The purpose of the present work is to improve the thermal design of these dryers. From experiments performed on an industrial Naratherm ${ }^{\circledR}$ paddle dryer and the literature (Yamahata and Izawa, 1985), a simple model has

*To whom correspondence should be addressed 
been developed. Since the drying process is both a dewatering process and a solid forming process with a "reverse granulation" phase from the wet to the dry solid, the sludge properties depend of the sludge history in the dryer itself. It was thus necessary to design a set of laboratory scale experimental techniques for a complete characterization of sludge during drying. Using these properties, the model is validated by comparison of the experimental and computed drying kinetics.

\section{SLUDGE CHARACTERIZATION}

The activated sludge comes from a biological wastewater treatment plant (Jalbert, 2002), which receives $85 \%$ of industrial wastewater and $15 \%$ of municipal one and annually produces around 400 tons of dry sludge. Before drying, the characterized activated sludge is :
- pumped from the aerated settling tanks, at a $4 \mathrm{~g} / \mathrm{L}$ solid concentration, to a $10 \mathrm{~m}^{3}$ storage tank;

- thickened by dissolved-air flotation up to a $60 \mathrm{~g} / \mathrm{L}$ solid concentration and stored;

- dewatered by centrifugation up to a moisture content of $3.52 \mathrm{~kg}$ water $/ \mathrm{kg}$ dry mater and stored in a $0.7 \mathrm{~m}^{3}$ plug tank.

\section{Mass Composition}

The main composition characteristics of the sludge are reported in Table 1. For the determination of the volatile solid content, 20 grams of dry ground sludge are heated at $550^{\circ} \mathrm{C}$ during two hours. This gives a rough estimate of the organic fraction, considering that, at this temperature level, the decomposition of inorganic salts is restricted to magnesium carbonate and that some of the organic complex will only oxidize around $700^{\circ} \mathrm{C}$. The elementary analysis leads to a chemical formula closed to the cellulose one $\left(\mathrm{C}_{6} \mathrm{H}_{12} \mathrm{O}_{5}\right)_{\mathrm{n}}$.

Table 1: Main composition characteristics of the chosen sewage sludge.

\begin{tabular}{|c|c|c|c|c|c|}
\hline $\begin{array}{c}\mathrm{W} \\
(\mathbf{k g} / \mathbf{k g})\end{array}$ & $\begin{array}{c}\text { Volatile solid content } \\
(\boldsymbol{\%} \text { DM) }\end{array}$ & $\begin{array}{c}\text { Carbon } \\
(\% \mathbf{D M})\end{array}$ & $\begin{array}{c}\text { Oxygen } \\
(\boldsymbol{\%} \mathbf{D M})\end{array}$ & $\begin{array}{c}\text { Hydrogen } \\
(\% \mathbf{D M})\end{array}$ & $\begin{array}{c}\text { Nitrogen } \\
(\% \mathbf{D M})\end{array}$ \\
\hline 3.54 & 86 & 46.7 & 22.1 & 6.9 & 7.3 \\
\hline
\end{tabular}

\section{Specific Heat}

Specific heat is an important parameter for sludge processing, especially for dry sludge temperature control. After a drying process and for safety reasons, the dry sludge is often cooled down to ambient temperature in a jacketed screw conveyor. The specific heat is a function of moisture content and temperature. The specific heat per $\mathrm{kg}$ of wet sludge is:

$$
\mathrm{C}_{\mathrm{p}}(\mathrm{W})=\frac{\mathrm{W}}{1+\mathrm{W}} \mathrm{C}_{\mathrm{pw}}+\frac{1}{1+\mathrm{W}} \mathrm{C}_{\mathrm{pDM}}
$$

where $\mathrm{C}_{\mathrm{pw}}$ and $\mathrm{C}_{\mathrm{pDM}}$ are the specific heat of the water and the dry sludge.

The specific heat of the dry sludge is measured using a C80 calorimeter (Setaram, Caluire, France) for a range of temperature between 35 and $105^{\circ} \mathrm{C}$. A linear expression may be used:

$$
\mathrm{C}_{\mathrm{pDM}}=1434+3.29 \mathrm{~T}
$$

with the temperature $\mathrm{T}$ in degree Celsius.

\section{Sorption Isotherm}

Important difficulties are met when determining sludge sorption isotherms at drying temperatures, due to the incompatibility between the high biological activity of most sludge and the necessity to reach thermal equilibrium. A fast transient method was elaborated and tested for a large range of products (Ferrasse and Lecomte, 2004; Arlabosse et al., 2003). This method, using a thermogravimetric analyzer (TGA) coupled with a differential scanning calorimeter DSC111 (Setaram, Caluire, France) in isothermal mode, was successfully applied to sludge description. Sorption isotherm is plotted on Figure 1. The transition between free and bound water appears closed to $0.9 \mathrm{~kg}$ water $/ \mathrm{kg}$ dry matter.

\section{Total Heat of Desorption}

The TGA-DSC apparatus also enables a direct 
and continuous measurement of the total heat of sorption as a function of the moisture content. The total heat of sorption is derived from the calorimetric signal and the mass loss (Ferrasse and Lecomte, 2004). As can be seen on Figure 2, the isosteric heat of sorption can be neglected for $\mathrm{W} \geq 0.2 \mathrm{~kg}$ water $/ \mathrm{kg}$ dry matter but can double at low moisture content.

\section{Drying Kinetic in a Batch Indirect Agitated Dryer}

At laboratory scale, a batch dryer (Ferrasse et al., 2002) was specially designed for the investigation of drying kinetics, of the heat transfer coefficient evolution and of the mechanical torque necessary for stirring. It consists of a $20 \mathrm{~cm}$ diameter Teflon cylindrical vessel screwed onto the top of metallic plates, which simulate the wall of the dryer and its heating system. The stirring device consists of three 2 $10^{-2} \mathrm{~m}$ wide and $1610^{-2} \mathrm{~m}$ long blades, sloped at $45^{\circ}$, fixed on a vertical shaft. The vertical distance between two consecutive blades is equal to $2510^{-3} \mathrm{~m}$. Static scrapers are fixed on the Teflon cell to break up the sludge. A motor supplies a constant rotation speed to the stirred. A meter, which monitors the torque during drying, is incorporated into the stirrer drive. Drying kinetics are calculated from an energy balance (Chavez, 2004), knowing the electrical power supplied by the heating system, the specific heat and the total heat of desorption of the sludge. The drying curve of the investigated activated sludge is plotted on Figure 3.

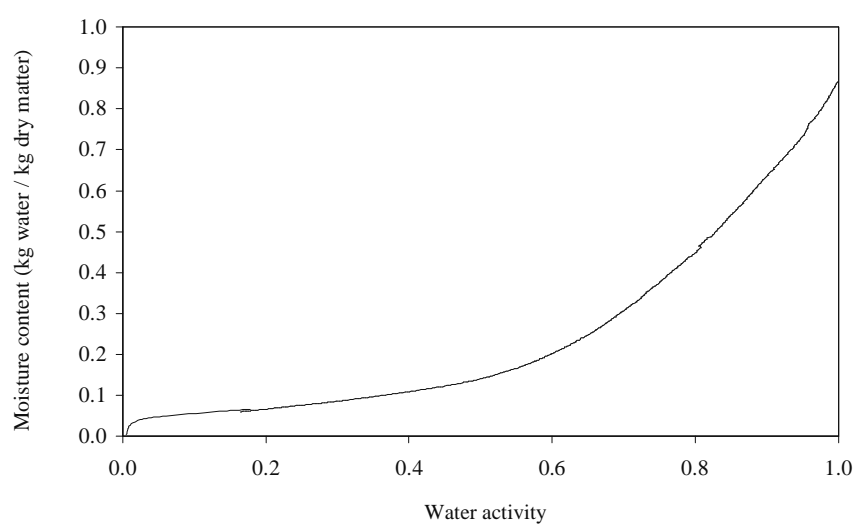

Figure 1: Desorption isotherm of the sludge measured at $95^{\circ} \mathrm{C}$

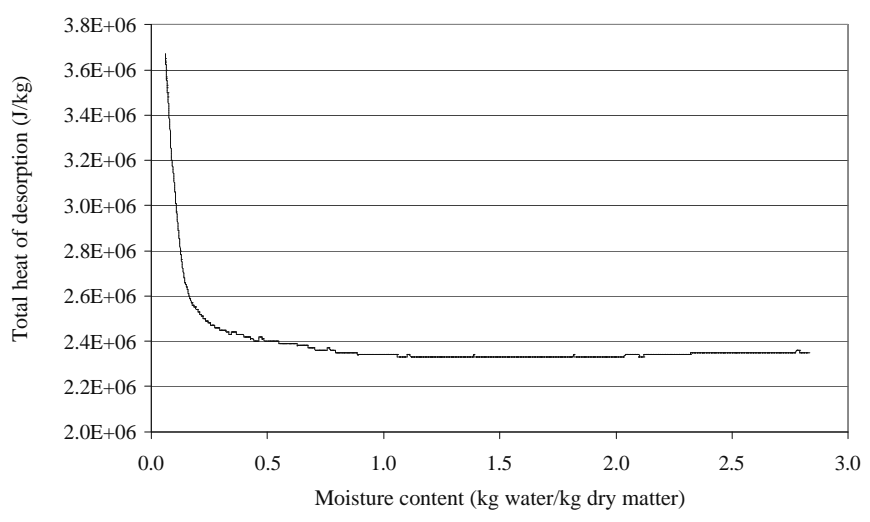

Figure 2: Total heat of sorption measured at $95^{\circ} \mathrm{C}$

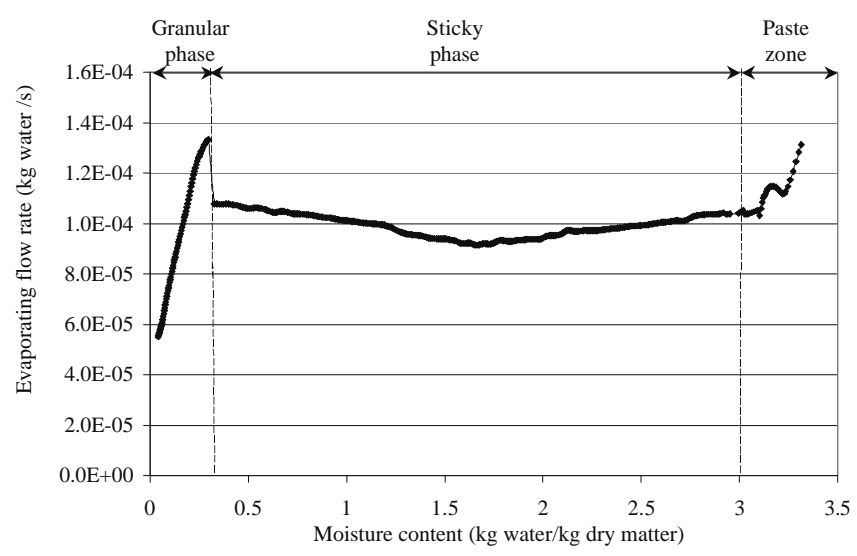

Figure 3: Drying kinetic of the activated sludge in the batch dryer 
Up to a moisture content of $3 \mathrm{~kg}$ water $/ \mathrm{kg}$ dry matter, the sludge looks like a fluid and the decrease of the evaporating flow rate might be due to a reduction of the contact surface between the sludge and the heated wall or to the formation of a thin layer of dry sludge between the heated wall and the first blade. Between 3 and $0.32 \mathrm{~kg}$ water $/ \mathrm{kg}$ dry matter, the sludge becomes sticky and the contact between the sludge and the heated wall is scarce. The vertical design of the dryer, in which the sludge is not compressed against the heated wall, probably explains this behavior. At the end of this sticky phase, the granular phase appears. Moist sludge touches again the heated wall and the evaporating flow rate increases to the initial value, when the heated surface is fully recovered by the granular phase. The mean evaporating flow rate per unit surface area of the dryer are given in Table 2 for the three drying zones.

Table 2: Mean evaporating flow rate per surface area of the dryer, $F$ in $\mathrm{kg}$ water $/ \mathrm{m}^{2} \mathrm{~h}$ for the three drying phases.

\begin{tabular}{|c|c|c|c|c|}
\hline $\begin{array}{c}\mathrm{W}_{\text {sticky }} \\
(\mathbf{k g} / \mathbf{k g} \mathbf{D M})\end{array}$ & $\begin{array}{c}\mathrm{W}_{\text {granular }} \\
(\mathbf{k g} / \mathbf{k g} \text { DM })\end{array}$ & $\mathrm{F}_{\text {paste }}$ & $\mathrm{F}_{\text {sticky }}$ & $\mathrm{F}_{\text {granular }}$ \\
\hline 2.99 & 0.32 & 12.44 & 11.53 & 13.81 \\
\hline
\end{tabular}

\section{PADDLE DRYER MODEL}

\section{Dryer Description}

Paddle dryer are classified as indirect drying systems, which are mechanically designed to overcome the sticky phase without recirculation of the dry product.

In the previously described wastewater treatment plant, the Naratherm ${ }^{\circledR}$ paddle dryer consists of a 4.08 $\mathrm{m}$ long horizontal jacketed trough, through which pass two $22 \mathrm{rpm}$ rotating shafts. On each shaft, hollow wedge-shaped paddles are welded. To ensure a good plugflow, the paddles of both shafts intermesh. The sludge is fed into one end of the trough and flows by gravity and mixing to the opposite end of the trough, where the dry material is discharged. All metallic surfaces in contact with the sludge (the jacket, the hollow shafts and paddles) are heated with a saturated vapor at a pressure close to 6 bar. This 32 $\mathrm{m}^{2}$ contact surface area is self cleaned according to friction forces induced by rotors motion. Vapors evolved during processing are carried out via a central exhaust port.

\section{Physical State o the Sludge in the Dryer}

Some experiments were performed on this industrial paddle dryer. As the production of small dry pellets was significant, $45 \%$ of the dry product was recirculated in the dryer. The feeding flow rate was, thus, equal to $267 \mathrm{~kg}$ of dry solid per hour and the inlet moisture content of the sludge $1.5 \mathrm{~kg}$ water $/ \mathrm{kg}$ dry matter. The residence time of the sludge in the dryer was estimated to five and a half hours. The moisture content distribution along the dryer is plotted on Figure 4.

At the dryer inlet, the sludge has a pasty consistency. As its moisture content decreases, the sludge becomes sticky and breaks into pellets. The transition between the pasty phase to the granular one appears at a distance of $z_{\text {transition }}=1.43 \mathrm{~m}$ from the dryer inlet, this corresponds to $0.35^{*} \mathrm{~L}$, $\mathrm{L}$ being the dryer length. The outlet moisture content of the sludge is around 0.07 $\mathrm{kg}$ water / $\mathrm{kg}$ dry matter.

This general behavior has been reported some years ago by Yamahata and Izawa (1985). These authors experimentally studied the drying kinetics of two different types of sludge with a paddle dryer at a pilot scale. They found that the dryer could be divided into two different parts. In the first one, called the paste zone, the sludge is packed fully whereas, in the second part called the lump zone, the sludge is packed to only about half of the full volume. And according to their comments, the length of the paste zone ranges between $0.26 * \mathrm{~L}$ and $0.33 * \mathrm{~L}$.

\section{Simple Paddle Dryer Model}

The following assumptions were made:

- The dryer could be divided into a paste zone and a granular one;

- The paste zone ranges between the dryer inlet and $\mathrm{Z}_{\text {transition }}=1.43 \mathrm{~m}$;

- In the granular zone, the product height in the dryer is equal to the paddle diameter and, thus, 
the contact surface is reduced to the sum of the two mixer shafts surface, the shaft mounted paddles surface and a small part of the jacketed trough surface. A linear decrease of the evaporating flow rate per heated surface of the dryer with the moisture content is assumed;

- For the paste zone, the evaporating flow rate per unit surface of the dryer is assumed to be constant and equal to the value recorded at the lab scale

- For the granular zone, the linear decrease of the evaporating flow rate per heated surface of the dryer with the moisture content is given by equation (3):

$\mathrm{F}_{\text {granular }}=\mathrm{a}^{*} \mathrm{~W}+\mathrm{b}$ for $0.05 \leq \mathrm{W} \leq \mathrm{W}_{\text {granular }}$

where $\mathrm{a}$ and $\mathrm{b}$ were estimated to $34.38 \mathrm{~kg}$ dry matter $/ \mathrm{m}^{2} \mathrm{~h}$ and $4.58 \mathrm{~kg}$ water $/ \mathrm{m}^{2} \mathrm{~h}$, respectively.

Finally, assuming a plug flow (Utvik, 1991) and a homogeneous moisture distribution in each cross section of the dryer, the following mass balance can be written on a small control volume:

$$
\dot{\mathrm{m}}_{\mathrm{DM}}[\mathrm{W}(\mathrm{z}+\mathrm{dz})-\mathrm{W}(\mathrm{z})]=-\mathrm{F} \frac{\mathrm{A}}{\mathrm{L}} \mathrm{dz}
$$

where $\dot{\mathrm{mDM}}$ and $\mathrm{Adz} / \mathrm{L}$ are the dry mass flow rate and the elementary heated surface, respectively.

This leads to:

$$
\begin{aligned}
& \mathrm{W}(\mathrm{z})=\mathrm{W}(\mathrm{z}=0)-\frac{\mathrm{F}}{\mathrm{m}_{\mathrm{DM}}} \frac{\mathrm{A}}{\mathrm{L}} \mathrm{z} \text { for } \mathrm{z} 1.43 \mathrm{~m} \\
& \mathrm{~W}(\mathrm{z})=\mathrm{W}\left(\mathrm{z}_{\text {transition }}\right) \\
& \exp \left(-\frac{\mathrm{a}}{\mathrm{m}_{\mathrm{DM}}} \frac{\mathrm{A}}{\mathrm{L}}\left(\mathrm{z}-\mathrm{z}_{\text {transition }}\right)\right)
\end{aligned}
$$

for $1.43 \mathrm{~m}<\mathrm{z}$

Using this simple model, the moisture content distribution along the dryer can be computed. As can be seen on Figure 4, the agreement between the calculated drying kinetic and the experimental data is good.

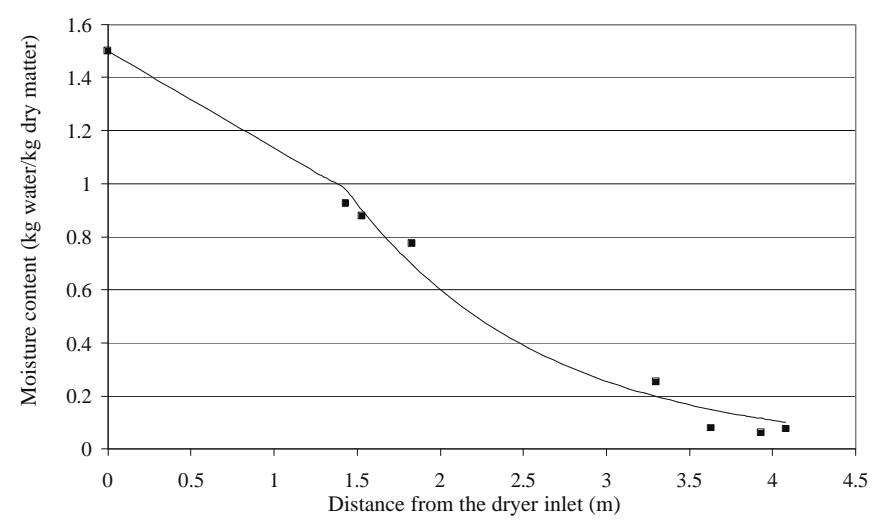

Figure 4: Comparison between the computed (line) and experimental (point) drying kinetics

\section{SUMMARY}

The purpose of this work was to improve the thermal design of paddle dryers. A set of laboratory scale experimental techniques have been designed for a complete characterization of sludge during drying. This includes the characterization of some intrinsic properties, like the composition, the specific heat, the sorption isotherm or the total heat of desorption, but also the determination of the drying kinetic in a batch agitated dryer. A simple model of the continuous industrial dryer has been developed. The dryer is divided into two parts, depending on the consistency of the sludge (pasty or granular). We assumed a constant evaporating flow rate in the pasty zone and a linear decrease with the moisture content in the granular zone. The agreement with the experimental data is good. 


\section{ACKNOWLEDGMENT}

The authors are grateful to the Midi-Pyrénées Region (France) for is financial support during this work.

\section{NOMENCLATURE}

\begin{tabular}{|c|c|c|}
\hline A & Heated surface & $\left(\mathrm{m}^{2}\right)$ \\
\hline $\mathrm{a}$ & Constant & $\left(\mathrm{kg}\right.$ dry matter $\left./ \mathrm{m}^{2} \mathrm{~h}\right)$ \\
\hline $\mathrm{b}$ & Constant & (kg water $\left./ \mathrm{m}^{2} \mathrm{~h}\right)$ \\
\hline $\mathrm{C}_{\mathrm{p}}$ & Specific heat & $(\mathrm{J} / \mathrm{kg} \mathrm{K})$ \\
\hline $\mathrm{F}$ & $\begin{array}{l}\text { Evaporating flow rate } \\
\text { per unit surface of the } \\
\text { dryer }\end{array}$ & ( $\mathrm{kg}$ water $/ \mathrm{m}^{2} \mathrm{~h}$ ) \\
\hline $\mathrm{L}$ & Dryer length & (m) \\
\hline $\mathrm{m}$ & Mass flow rate & $(\mathrm{kg} / \mathrm{s})$ \\
\hline $\mathrm{T}$ & Temperature & $\left({ }^{\circ} \mathrm{C}\right)$ \\
\hline W & Moisture content & $\begin{array}{r}\text { (kg water } / \mathrm{kg} \text { dry } \\
\text { matter) }\end{array}$ \\
\hline $\mathrm{z}$ & $\begin{array}{l}\text { Distance from the } \\
\text { dryer inlet }\end{array}$ & $(\mathrm{m})$ \\
\hline
\end{tabular}

\section{Subscript}

DM Dry matter

w Water

\section{REFERENCES}

Arlabosse, P., Rodier, E., Ferrasse, J.H., Chavez, S. and Lecomte, D. (2003), Comparison between static and dynamic methods for sorption isotherm

measurements, Drying Technology, (21), 3, pp. 479 - 498

Chavez, S. (2004), Séchage par contact avec agitation de boues résiduaires urbaines : influence de leur origine et des conditions opératoires sur la cinétique de séchage et les caractéristiques des boues sèches et des rejets gazeux, $\mathrm{PhD}$ Thesis, University of Perpignan, France, 183p (in French).

Chen, G., Yue, P.L. and Mujumdar, A.S. (2002), Sludge dewatering and drying, Drying Technology, (20), 4\&5, pp. 883-916.

Ferrasse, J.H., Arlabosse, P. and Lecomte, D. (2002), Heat, Momentum and Mass Transfer Measurements in Indirect Agitated Sludge Dryer, Drying Technology, (20), 4\&5, pp. 749-769.

Ferrasse, J.H. and Lecomte, D. (2004), Simultaneous heat-flow differential calorimetry and thermogravimetry for fast determination of sorption isotherm and heat of sorption in environmental or food engineering, Chemical Engineering Science, (59), 6, pp. 1365-1376.

Jalbert, C. (2002), Epuration des eaux résiduaires industrielles et urbaines des Pays d'Olmes et séchage des boues, in Proceedings of «Quelles évolutions technologiques pour mieux garantir et pérenniser une gestion optimale des boues ?», Ecole des Mines d'Albi Carmaux Ed., Albi (France), ISBN 2-9511591-0-2, pp. 94-103 (in French).

Utvik, A.O. (1991), Sludge drying in the Rotadisk Dryer, Environment Northern Seas Conference Report, 2, pp. 169-174.

Yamahata, Y. and Izawa, H. (1984), Experimental study on application of paddle dryers for sludge cake drying, Proceedings of the $4^{\text {th }}$ International Drying Symposium, IDS'84, Kyoto, pp. 719-724. 